\title{
Marketing Strategies in Times of Crisis Exploring More Digital Strategies in Luxury Industry
}

\author{
Rui Cheng ${ }^{1, *}$, Jianyi Zhu ${ }^{2}$, Xiuheng Zhu ${ }^{3}$, Churui Zhang ${ }^{4}$ \\ ${ }^{1}$ School of business, university of creative arts, Epsom, KT18 5BE, UK \\ ${ }^{2}$ School of International Business, Xiamen University Tan Kah Kee College, Fujian, Zhangzhou 363105, China \\ ${ }^{3}$ School of Economics and Management, Beijing Jiaotong University, Beijing, Beijing 100044, P.R.China \\ ${ }^{4}$ School of Business, Newcastle university, Newcastle,NE1 7RU,UK \\ *Corresponding Author. Email: claireyixi0311@gmail.com
}

\begin{abstract}
With the outbreak of covid-19, digital marketing has become a turning point for the phenomenon of luxury offline activities being blocked. Marketers and consumers are paying more attention on this emerging marketing approach from traditional mass. In order to understand how luxury goods continue to use digital channels to attract young consumers, this work first clarifies three criterions based on relevant literatures, including social media, digital technology service, and e-commerce platform. Then adopt the quantitative and qualitative methods are adopted to analyze the different usage of luxury online and offline users and some interesting trends related to digitization. The final research results indicate that luxury industry can appeal to young consumers through innovation and management of the second-hand market, strengthening management of various channels of online shopping channels and redeveloping virtual fitting rooms with the help of VR technology.
\end{abstract}

Keywords : young consumers, social media, e-commerce, virtual technology

\section{INTRODUCTION}

The outbreak of the Covid-19 has caused the fashion industry to face an unprecedented crisis. The overall sales of the global luxury goods market in the first quarter fell by $25 \%-30 \%$, the scale of the luxury market will shrink by $15 \%$ to $30 \%$, and the loss is expected to reach 60 to 70 billion euros [1]. Consumer spending cuts during the lockdown of the epidemic, the closure of sales stores, and the troubles caused by the global economic recession have become factors influenced in the luxury sales. In order to save this crisis, the acceleration of digitalization and innovation for luxury brands is the general trend. In 2020, Gucci launched its live shopping service Gucci Live on its official App, and cooperated with Snap to launch an AR trial shoe experience to provide an online interactive mode with consumers. Gucci's sales rebounded strongly by $24.6 \%$ to 2.168 billion euros [2]. It can be seen that the brand uses Internet technology to upgrade the brand experience and start to recognize the concept of luxury brand. Some $130 \%$ of market growth in the next seven years will be attributed to the Millennial generation [3]. The digital behavior of the millennials will promote a significant change in the relationship between luxury brands and consumers. In order to seize the main consumers, luxury companies have to rethink their digital strategies. In this paper, there will be a study on what can luxury brands continue to do to target young consumers on digital channel even after pandemic. Digital upgrade helps the luxury industry to survive and grow in the post-COVID-19 world by starting to appeal to young consumers.

\section{LITERATURE REVIEW}

Luxury brands in digital marketing has been implemented three different strategies to navigate the difficult times. The theme of three strategies are social media, digital technology service, and diversified online shopping platform.

First, Luxury goods establish an emotional connection with consumers through social media. New media KOLs and celebrities promote luxury goods through Instagram, Twitter, and Weibo. Most of brands are working with Instagram bloggers to strengthen their influence on the young generation. Dorie and Loranger stated that social media more broadly had a big impact on younger shoppers, with more than $80 \%$ of Gen $\mathrm{Z}$ 
influenced by social media in their shopping and $74 \%$ of millennials. These numbers drop significantly when compared to Generation X (58\%) and Baby Boomers (41\%)[4]. Otherwise, luxury brands convey the concept of brand rejuvenation through social media to change consumers' stereotypes of luxury brands. Collaborations with unexpected creators, like Coco Capitan, a Spanish artist, which helped to reimagine the famous logo by scribbling over the traditional one with Graffiti elements, and the rapper Gucci Mane, which exemplifies the marriage of glamour and gangster are signs for Gucci's new direction. Consequently, Gucci broke with the main principle of luxury brand management, namely exclusivity, making the brand approachable, especially for young consumers. In this context, the new store concepts are aimed towards winning over the hearts of Millennials and focus on social media goes as far as exclusively launching new collections on Instagram [5].

Second, digital technology brings a different experience to consumers with the rise of AI and VR technology. With the diversification of online identities, consumers have their own unique styles and character images that they want to shape on different online platforms. People want to express themselves, especially generation $\mathrm{Z}$, they are more willing to purchasing skins in games and changing consumption habits make games not only add entertainment attributes, but also social attributes, layout virtual worlds, and enhance the influence of younger brands [6].

Third, the construction of a diversified online shopping platform has brought a lot of convenience to consumers. It not only further broadens the functions of luxury products, but also the products also accelerate the coverage model in multiple fields. Online shopping makes shopping easy and fun, and the items you can browse for an hour on the Internet are probably more than the items you see in a day on the commercial street [7]. Shopping convenience is one of the primary considerations for consumers, the convenience that consumers consider when choosing online shopping is the convenience of time, which can save time without being restricted by time, on the other hand it is the convenience of the region, Jarvenpaa and Todd (1996) stated that It is amazing for consumers can access to a wide range of products, before people could not go to the traditional shop, but now they have massive choice online, the internet is an amazing access[8].

\section{RESEARCH METHODOLOGY}

\subsection{Design}

we use questionnaires and interviews to conduct the research, there are 184 participants join the survey, the survey including 12 questions. The topic of the questionnaire is luxury online and offline consumers' sense of use. The purpose is to find the shortcomings of online management through the comparison of online and offline luxury goods marketing., the survey is in the appendix.

1. Your age
$5-16$ years old
17-28 years old

29-50 years old Over 50 years old

2. Your gender

Female Male

3. How often do you purchase luxury goods each month?

$\begin{array}{ll}\text { Never } & \text { Seldom } \\ \text { Sometimes } & \text { Often } \\ \text { Usually } & \end{array}$

4. If your friends recommend you an online luxury shopping website, are you willing to buy it through this channel?

$\begin{array}{ll}\text { Strongly disagree } & \text { Disagree } \\ \text { Neutral } & \text { Agree }\end{array}$

Strongly agree

5. Which way have you ever used to purchase luxury goods?
Physical store
Online store
Physical store \& Neither of them online store

6. How often do you purchase luxury goods online? (only for online store)

Never Seldom
Often Every day

7. How often do you purchase luxury goods online? (only for Physical store \& online store)

$\begin{array}{ll}\text { Never } & \text { Seldom } \\ \text { Often } & \text { Every day }\end{array}$

8. How often do you purchase luxury goods offline? (only for Physical store)

$\begin{array}{ll}\text { Never } & \text { Seldom } \\ \text { Often } & \text { Every day }\end{array}$

9. How often do you purchase luxury goods offline? (only for Physical store \& online store)

$$
\text { Never Seldom }
$$




\section{Often Every day}

10. Below are the ways to buy luxury goods. Please rank them according to the consumption frequency from high to low. (only for online store)

Purchasing in Purchasing in online
online stores
stores

Selecting in offline store and purchasing in online store

11. Below are the ways to buy luxury goods. Please rank them according to the consumption frequency from high to low. (only for Physical store)

$\begin{array}{lll}\begin{array}{l}\text { Purchasing } \\ \text { physical stores }\end{array} & \text { in } \begin{array}{l}\text { Purchasing in online } \\ \text { stores }\end{array}\end{array}$

Selecting in online store and purchasing in offline store

12. Below are the ways to buy luxury goods. Please rank them according to the consumption frequency from high to low. (only for Physical store \& online store)

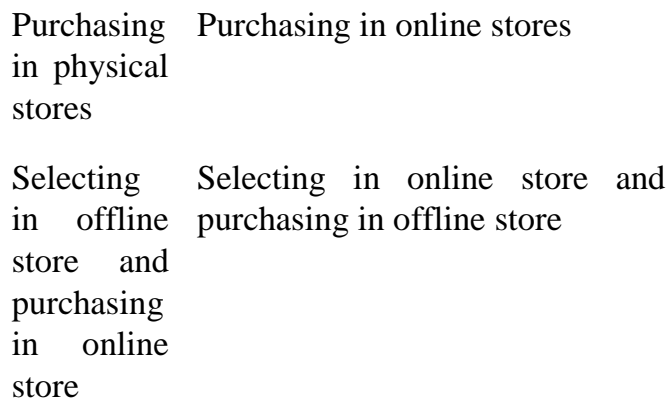

13. Below are the ways to buy luxury goods online. Please rank them according to the consumption intention from high to low. (only for online store)
Official web
Online store
Social network purchasing Live streaming agency

14. Below are the ways to buy luxury goods. Please rank them according to the consumption intention from high to low. (only for Physical store \& online store)
Official web
Online store
Social network purchasing
agency
Live streaming

15. The following are the ways to publish luxury news, please rank them according to your contact times. (only for online store)

Physical store

Official web

\section{Friends recommendation Magazine \\ Online ads \\ Mobile phone apps}

16. The following are the ways to publish luxury news, please rank them according to your contact times. (only for Physical store)
Physical store
Official web
Friends recommendation Magazine
Online ads
Mobile phone apps

17. The following are the ways to publish luxury news, please rank them according to your contact times. (only for Physical store \& online store)
Physical store
Official web
Friends recommendation Magazine
Online ads
Mobile phone apps

18. The following are the factors of luxury online purchasing, please rank them according to your perception. (only for online store)
Quality
Style
Price
Web trust
Shopping experience
Convenience

19. The following are the factors of luxury online purchasing, please rank them according to your perception. (only for Physical store)

$\begin{array}{ll}\text { Quality } & \text { Style } \\ \text { Price } & \text { Risk perception } \\ \text { Shopping experience } & \text { Convenience }\end{array}$

20. The following are the factors of luxury online purchasing, please rank them according to your perception. (only for Physical store \& online store)

$\begin{array}{ll}\text { Quality } & \text { Style } \\ \text { Price } & \text { Web trust } \\ \text { Shopping experience } & \text { Convenience }\end{array}$

Risk perception 
21. Please answer questions according to your experience and attitude of the luxury online purchasing.(1="strongly disagree", 5="strongly agree", only for online store)

\begin{tabular}{|c|c|c|c|c|c|}
\hline & 1 & 2 & 3 & 4 & 5 \\
\hline $\begin{array}{l}\text { Compared with offline shopping, purchasing luxury online is } \\
\text { more convenient, with more information and products to } \\
\text { choose from, which saves time }\end{array}$ & & & & & \\
\hline $\begin{array}{l}\text { Compared with offline shopping, it is easier to purchase } \\
\text { satisfying luxury online }\end{array}$ & & & & & \\
\hline $\begin{array}{l}\text { Compared with offline shopping, communicating with } \\
\text { merchants is easier }\end{array}$ & & & & & \\
\hline $\begin{array}{l}\text { Compared with offline shopping, it is easier to find correct } \\
\text { goods. }\end{array}$ & & & & & \\
\hline $\begin{array}{l}\text { The reputation of online merchants is benefit for you to } \\
\text { purchase luxury }\end{array}$ & & & & & \\
\hline $\begin{array}{l}\text { Online consumers' comments have advantage to your } \\
\text { purchase }\end{array}$ & & & & & \\
\hline $\begin{array}{l}\text { The personalized service provided by online luxury store are } \\
\text { helpful for your purchase }\end{array}$ & & & & & \\
\hline Purchasing luxury online can effectively avoid blindness & & & & & \\
\hline
\end{tabular}

22. Please answer them according to your experience and attitude of the luxury online purchasing. $(1=$ "strongly disagree", 5="strongly agree", only for Physical store \& online store)

\begin{tabular}{|l|l|l|l|l|l|}
\hline & 1 & 2 & 3 & 4 & 5 \\
\hline $\begin{array}{l}\text { Compared with offline shopping, purchasing luxury online } \\
\text { is more convenient, with more information and products to } \\
\text { choose from, which saves time }\end{array}$ & & & & \\
\hline $\begin{array}{l}\text { Compared with offline shopping, it is easier to purchase } \\
\text { satisfying luxury online }\end{array}$ & & & & \\
\hline $\begin{array}{l}\text { Compared with offline shopping, communicating with } \\
\text { merchants is easier }\end{array}$ & & & & \\
\hline $\begin{array}{l}\text { Compared with offline shopping, it is easier to find correct } \\
\text { goods. }\end{array}$ & & & & \\
\hline $\begin{array}{l}\text { The reputation of online merchants is benefit for you to } \\
\text { purchase luxury }\end{array}$ & & & & & \\
\hline $\begin{array}{l}\text { Online consumers' comments have advantage to your } \\
\text { purchase }\end{array}$ & & & & & \\
\hline $\begin{array}{l}\text { The personalized service provided by online luxury store } \\
\text { are helpful for your purchase }\end{array}$ & & & & & \\
\hline Purchasing luxury online can effectively avoid blindness & & & & \\
\hline
\end{tabular}

After conducting the survey, actual interviews are started with GenZ and Millenial age groups, and 10 oneon-one interviews were conducted in two days. At the beginning of each interview, we will inform the participants that they are free to express their opinions. The interview is categorized into 3 parts of themes which aims to gain a deeper understanding of participants' perceptions and motivation clearly. The direction of 
interview questions is mainly based on the results of the questionnaire, which focus on the online store provides consumers with virtual technology service, luxury second-hand market demand, online shopping channels management. Our goal is to establish a personal connection with the participants, and combine the emotional resonance and enough knowledge to complete this interview.

\subsection{Data Analysis and Discussion}

Data gathered from the survey are analyzed by excel. According to excel, $64 \%$ of consumers have at least used one online or offline channel to purchase luxury goods.

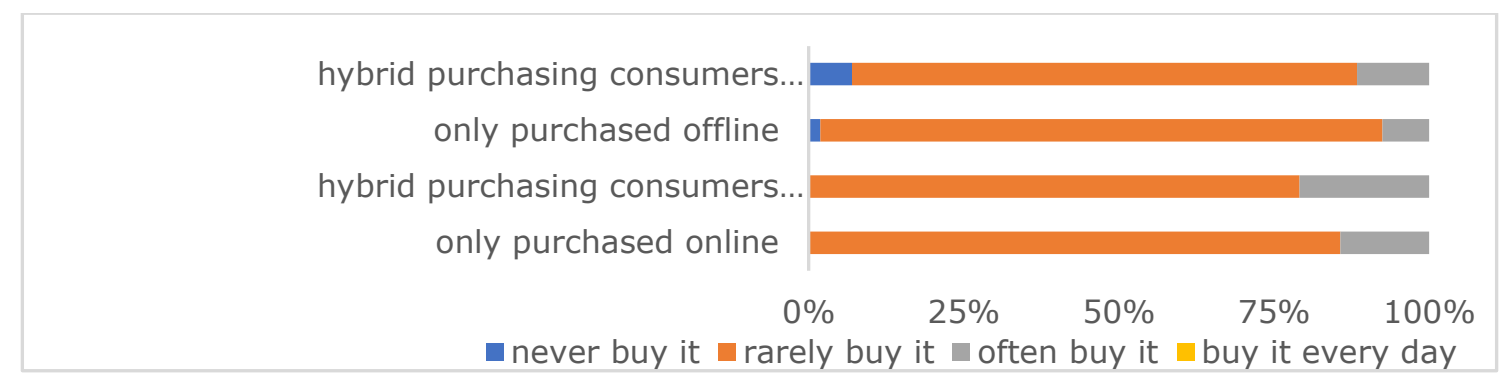

Figure 1. Purchasing frequency for different type of customers

It is apparent from the fig1 that less purchasing occupies the most in the frequency of people who purchase online, offline and the combination of online and offline. The ranking of goods purchasing methods claim that people who purchase online or offline tend to use their channel directly, with the mean mark of 2.64 in offline consumption and 2.24 in online consumption, instead of selecting other channels first and then purchase them in their original way. Same occasion can be found in hybrid purchasing consumers ( hybrid purchasing consumers refer to the combination of online and offline purchasing consumers), while they prefer offline purchasing the most, with 2.65. In addition, the interesting aspect is the perception of the rank of four online purchasing channels in online and hybrid consumers, which establish the same outcome, they both put official websites in the first place, with an average score of 3.33 and 3.4 respectively. Besides, among six luxury news implementing channels, both online and offline official shops are mostly welcomed.

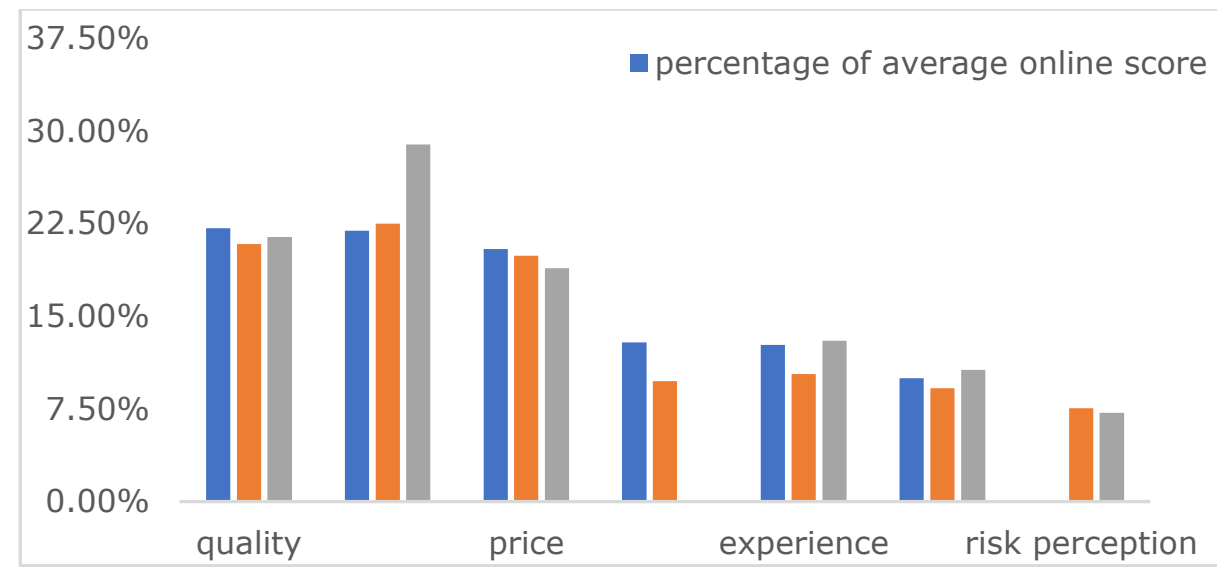

Figure 2. Luxury online buying factors

Factors that influence consumers purchasing attitude is the important part, in fig2, each part of score is turned into percentage because among these three ways(online, offline and hybrid), the number of people who answer this question is different. It can be seen that by far the greatest demands are price, style and quality, however, risk perception is not being focused very well.

The following questions are put in the Liket scale, the most striking result to emerge from the data is that consumers who apply the hybrid consumption method have a larger proportion to choose "I hate it" compared with the online group where the percentage of choosing 1 is 0 . Otherwise, nearly half of people in the online group strongly agree that online shopping is easier to satisfy their demand, which is two times larger than the hybrid purchasing group. Such highest agreement also occurred when online merchants own good reputation according to hybrid purchasing group, with $39 \%$. In addition, the largest difference can be found in the third statement, communicating with merchants is easier than in offline 
shop, $23 \%$ of hybrid users choose 1 , while $0 \%$ for online users.

There are three key findings according to the results of the in-depth interviews and survey carried out by us. First, as most interviewees mentioned, official website seemed to be their favorite online shopping channel. When asked why they would prefer to make luxurious consumption on official website, some then talked about their actual experiences or potential concerns of purchasing counterfeit products carelessly, which often happened to online consumptions in China, but such a phenomenon has never been seen when buying on the brand's official website. As mentioned earlier, influenced by the covid-19, most luxury brands had shut down most of their offline stores globally. However, due to the concerns of counterfeits, warranty, and quality issues, the wider access to the goods seemed not have shifted consumers' preference on official website purchase. Thus, online shopping channels must be strictly managed.

Next, the survey reveals that virtual technology are very popular with consumers, confronted to the massive shut-down of offline stores, consumers now have novel options to try the goods on-the virtual fitting room. Some participants excitedly described their online try-on experiences and all of them have evaluated this service positively. Forced by the global pandemic, luxury brands had to increase their spending on improving online services, while apparently, the growing spending indeed improved consumers' online shopping experiences, mainly with the help of new technologies such as VR. Otherwise, Participants also expressed their regret that the virtual fitting room is now removed from the ecommerce store due to technical problems, the digital technology experience has filled them with freshness, and they hope to have the opportunity to experience this service again. Thus, It's time to consider redeveloping the virtual fitting room.

Third, an interesting finding is that some participants showed great interests towards second-hand luxury goods market. As they explained, the rationale behind this phenomenon was that for young generations, constant consumption on luxurious good seems infeasible, whereas second-hand market provides them chances to exchange their goods with others, and so to get some nearly-new goods at acceptable prices. In addition, the trend of retro consumption also increases young consumers' wills to trade in second-hand market.

In terms of the implications of the results of the study for marketers. Based on finding one and finding two, marketers should continuously increase their spending on their IT, improving the performance of their online stores, particularly their official websites. Meanwhile, to cooperate with trustworthy retailers, such as Harrods, and Selfridges may also boost their online sales. Last but not least, as finding three shows, the second-hand market seems to have a great potential, especially when firms want to target young generations. Luxury brands may explore that new field for their future growth.

Additionally, for researchers who are interested about this area, above findings may be topics that worth further investigations.

\section{CONCLUSION}

Through the quantitative and qualitative methods we adopted including a survey with 12 questions that were completed by 184 participants, it is obvious that young people have great potential in the luxury consumer market, and digitalization will become a powerful factor to promote young people's luxury consumption. With the popularity of digital marketing strategies and impacts, the Youngers have ready access to information and advertising, although only a few of the top brands that really appeal to them can sustain their enthusiasm because of their high prices. This means that the mystery and illusion of luxury brands have been removed, followed by an increasing luxury consumption of young people. At the same time, the luxury consumption market still has great potential, especially for young people. More than $30 \%$ of our interviewers haven't bought anything on new media. The market will be further developed as more brands continue to invest in digital marketing. More specifically, with the increasing number of young generation luxury consumption, more effective strategies can be applied by luxury brands. For a case in point, virtual fitting rooms with the help of virtual reality technology, and the online second-hand market are especially appealing to young people according to our research. Overall, digital upgrades definitely contribute to the recovery and development of the luxury industry in the post-COVID-19 world by exploring a broader market of young consumers. In the future, an increasing number and kinds of digital upgrades can be expected. First, more efficient multi-platform advertising is required to attract more customers because as we can see from the data, over one-third participant hasn't tried to buy luxury things online. Then, virtual reality technology can benefit the luxury industry a lot by providing a more convenient and efficient shopping experience. Meanwhile, luxury companies can invest more in building official online second-hand shopping platforms. It is an inevitable trend that more young people choose second-hand products considering the value of money.

\section{REFERENCES}

[1] Claudia,D.(2020). Luxury after Covid-19: Changed for (the) Good?

https://www.bain.com/insights/luxury-aftercoronavirus.

[2] Maghan,M.(2020) Gucci’s new tech bet: Personalised video shopping, https://www.google.com.hk/amp/s/www.voguebusi 
ness.com/technology/gucci-live-personalisedvideo-shopping.

[3] Pamela,D.,(2019) 3 Ways Millennials And Gen-Z Consumers Are Radically Transforming The Luxury Market,

https://www.google.com/amp/s/www.forbes.com/si tes/pamdanziger/2019/05/29/3-ways-millennialsand-gen-z-consumers-are-radically-transformingthe-luxury-market.

[4] Dorie, David L.(2020) The multi-generation: Generational differences in channel activity, International Journal of Retail\&Distribution Management., New York. pp. 395-416.

[5] Feline, Katharina N.(2020) Drinking from the Fountain of Youth? Brand rejuvenation in the case of heritage luxury fashion brands, International Marketing \& Brand Management., New York. pp.38-39.

[6] Ksenija,M.(2020) Transcending the Physical Body: The influence of E-Sports on Digital Fashion. Global Fashion Conference., 4(2),72-73.

[7] vMary, Mary,G.(2001) Shopping online for freedom, control, and fun, California management review., 43 (2), 34-35.

[8] Shirrka, Peter T.(1996) Consumer reactions to electronic shopping on the World Wide Web International Journal of electronic commerce., pp. 59-88. 